Short Communication

\title{
Spodoptera albula susceptibility to Bacillus thuringiensis-based biopesticides
}

\author{
Kelly Cristina Gonçalves ${ }^{\mathrm{a}}$, Arlindo Leal Boiça Júnior ${ }^{\mathrm{a}}$, Rogerio Teixeira Duarte ${ }^{\mathrm{b}}$, \\ Laís Fernanda Moreira ${ }^{a}$, Joacir do Nascimento ${ }^{\mathrm{a}}$, Ricardo Antônio Polanczyk ${ }^{\mathrm{a}, *}$ \\ a São Paulo State University, College of Agricultural and Veterinary Sciences, Department of Crop Protection, Rod. Prof. Paulo Donato Castellane km 5, CEP 14884-900 \\ Jaboticabal, SP, Brazil \\ ${ }^{\mathrm{b}}$ Araraquara University, Avenida Maria Antonia Camargo de Oliveira, Vila Suconasa, CEP 14807120 Araraquara, SP, Brazil
}

A R T I C L E IN F O

\section{Keywords:}

Microbialcontrol

Gray-streaked armyworm moth

Pest management

\begin{abstract}
A B S T R A C T
Single concentration and virulence (mean lethal concentration) bioassays were performed to evaluate the susceptibility of $S$. albula second instar larvae to seven Bacillus thuringiensis-based biopesticides. Bioassays were conducted using three replicates and repeated three times at $25^{\circ} \mathrm{C}, 70 \pm 10 \% \mathrm{RH}$, and a $12: 12$ (light/dark) photoperiod; mortality was recorded seven days after treatment. The results were subjected to a Tukey's test and Probit analysis. Agree, DiPel SC, and XenTari achieved mortality rates of up to $80 \%$, with the first of these being the most virulent against $S$. albula. Different Dipel formulations showed different degrees of larvicidal activity.
\end{abstract}

\section{Introduction}

The gray-streaked armyworm moth Spodoptera albula (Walker, 1857) occurs from the USA to Paraguay (Zenker et al., 2010). The first record in Brazil was from the state of São Paulo, where up to 70 larvae per meter were found on peanut (Arachis hypogaea L.) (Teixeira et al., 2001). Spodoptera albula larvae are polyphagous, feeding on at least 55 plant species belonging to 29 families (Montezano et al., 2014).

The lack of products specifically targeting $S$. albula control in Brazil (Agrofit, 2018) makes it necessary to study efficient and non-aggressive strategies for environmental control; because $S$. albula outbreaks can otherwise lead to the unrestrained use of broad pesticides, as recently reported for Helicoverpa armigera (Hubner, 1808) (Thomazoni et al., 2013). This improper management has undesirable effects on the environment, as described by Nicolopoulou-Stamati et al. (2016).

Bacillus thuringiensis- (Bt-) based biopesticides have been used successfully against agricultural pests since the second half of the 20th century (Lacey et al., 2015; Polanczyk et al., 2017). Bergamasco et al. (2013) reported the susceptibility of $S$. albula to Cry and Vip toxins; however Bt-based biopesticides also contain spores which can contribute to toxicity (Burges et al., 1976).

\section{Material and methods}

Spodoptera albula rearing started with 100 adults collected from peanut in Jaboticabal (São Paulo) in January 2013. Specimens were identified by Prof. Dr. Roberto Zucchi (Luiz de Queiroz College of
Agriculture, University of São Paulo), because of adult morphological similarities between $S$. albula and Spodoptera eridania (Teixeira et al., 2001). The larvae were fed with an artificial diet (Di Bello et al., 2017) and adults with $10 \%$ sugar solution. After emergence, the adults were transferred to plastic cages $(25 \times 10 \mathrm{~cm})$ that were internally coated with filter paper for oviposition and egg collection every two days.

Seven Bt biopesticides were initially used in the preselective assays: Agree WP (B. thuringiensis aizawai CG 91; Certis USA, Columbia, MD, USA), BacControl WP (B. thuringiensis kurstaki; Vectorcontrol, Vihedo, SP, Brazil), Btt090 SC (B. thuringiensis tolworthi), DiPel SC, WG, and WP (B. thuringiensis kurstaki), and XenTari WG (B. thuringiensis aizawai). These were assayed against $60 \mathrm{~s}$ instar $S$. albula larvae, distributed in six replicates. Each replicate consisted of an amount of $500 \mu \mathrm{L}$ containing $3 \times 10^{8}$ spores $\mathrm{mL}^{-1}$ (Polanczyk et al., 2005), and was applied to a recipient ( $\varnothing 3.5 \mathrm{~cm}$ ) with $4.8 \mathrm{~cm}^{3}$ of artificial diet to which $10 \mathrm{~S}$. albula larvae had been added after air-drying. Those biopesticides that showed an $S$. albula mortality of at least $80 \%$ were then used in estimating values of $\mathrm{LC}_{50}$, using five concentrations and $900 \mathrm{~S}$. albula second instar larvae distributed in three replicates according to the methodology described above. Bioassays were repeated three times, conducted at $25^{\circ} \mathrm{C}, 70 \pm 10 \% \mathrm{RH}$, and under a $12: 12$ (light/dark) photoperiod; mortality was evaluated seven days after treatment, and Tukey's tests $(\mathrm{P} \leq 0.050)$ and Probit analyses (LeOra Software, Berkeley, CA, USA) were used for data analysis. Significant differences were based on nonoverlapping 95\% confidence intervals.

\footnotetext{
* Corresponding author.

E-mail address: rapolanc@fcav.unesp.br (R.A. Polanczyk).
} 


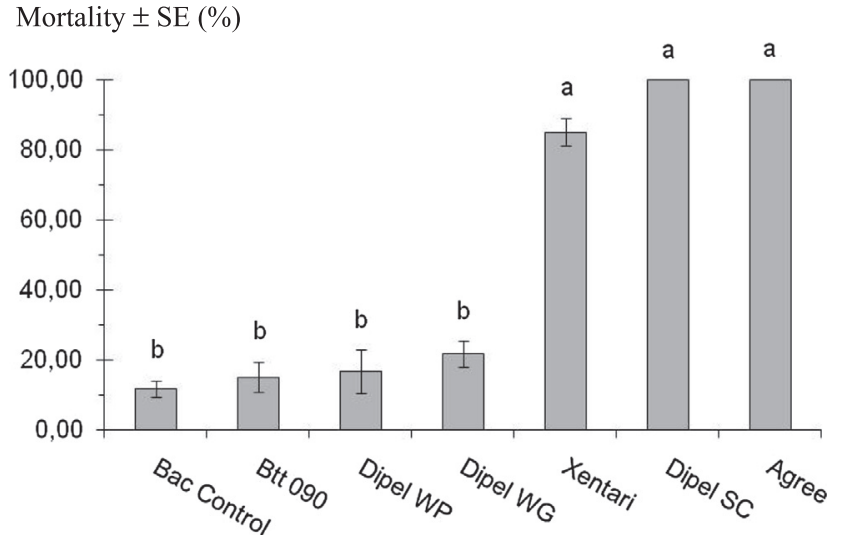

Fig. 1. Spodopera albula susceptibility (mortality \pm standard error) to Bacillus thuringiensis based biopesticides (Three bioassays means). Different letters mean significantly different mortalities (Tukey's Studentized Range test, $\mathrm{P}=0.05$ ).

Table 1

Bacillus thuringiensis based biopesticides $\mathrm{LC}_{50}$ values against Spodoptera albula

\begin{tabular}{lccll}
\hline Treatment & $\mathrm{n}^{\mathrm{a}}$ & Slope $\pm \mathrm{SE}$ & $\mathrm{LC}_{50}\left(\mathrm{CI}_{95} \%\right) \times 10^{5}$ & $\chi^{2 \mathrm{~b}}$ \\
\hline Agree & 900 & $0.84 \pm 0.05$ & $0.022(0.008-0.097)$ & 12.64 \\
Dipel SC & 900 & $0.52 \pm 0.05$ & $0.38(0.30-0.49)$ & 13.61 \\
Xentari & 900 & $1.01 \pm 0.07$ & $1164.64(1054.06-1288.66)$ & 3.83 \\
\hline
\end{tabular}

${ }^{\mathrm{a}} \mathrm{n}=$ number of insects per treatment.

b Chi-Square $(P>0.05)$.

\section{Results and discussion}

Mortality values for S. albula ranged from $12 \%$ to $100 \%$, the results for Agree, DiPel SC, and XenTari were statistically different from the other biopesticides and resulted in a mortality of at least $80 \%$ (Fig. 1). This mortality is mainly determined by Cry toxins that act either individually, or in combination increasing individual toxicity (Xue et al., 2005; Wei et al., 2015). Many factors can influence the effectiveness of a Bt toxin or strain against a given insect as has been recently reviewed by Jurat-Fuentes and Crickmore (2017). Agree, DiPel SC, and XenTari were then used in a dose response assay, with concentrations ranging from $1 \times 10^{3}$ to $9 \times 10^{4}$ spores $\mathrm{mL}^{-1}, 1 \times 10^{3}$ to $3 \times 10^{8}$ spores $\mathrm{mL}^{-1}$, and $3 \times 10^{7}$ to $3 \times 10^{8}$ spores $\mathrm{mL}^{-1}$, respectively, in order to calculate $\mathrm{LC}_{50}$ values (Table 1 ).

Spodoptera albula mortality caused by DiPel SC was higher than that shown by WG (dispersible granules) and WP (wettable powder) formulations, which achieved a mortality of approximately. Although the four toxins Cry1Aa, Cry1Ab, Cry1Ac, Cry2Aa are the main virulence factors in all the Dipel formulations, the differences in activity might be due to the batches of products (Shelton et al., 1993; Talekar and Shelton, 1993; Mohan and Gujar, 2001) or an effect of the formulation. Liquid formulations (SC) not only enhance the moisture content (Cush, 2006) but can also make the food more palatable resulting in increased pest mortality compared to dry formulations (WP and WG), as reported by Ahmedani et al. (2007).

The biopesticides DiPel SC, XenTari, and Agree all achieved mortality rates of at least $80 \%$ but differed significantly in their $\mathrm{LC}_{50}$ values. Agree and XenTari contain the Cry toxins Cry1Ac, Cry1C, Cry1D, and Cry2 (Agree); and Cry1Aa, Cry1Ab, Cry1C, and Cry1D (XenTari). Although little data exist for $S$. albula it is well established that Cry1C and to a lesser extent Cry1D have activity against other species of Spodoptera including S. exempta, S. exigua, S. frugiperda and S. littoralis (van Frankenhuyzen 2009). The observed differences between Agree and Xentari could be due to differences in the proportions of each toxin or differences in formulation.

Bt-based biopesticides can be a useful tool against pest outbreaks as reported by Broza et al. (1991) and Polanczyk et al. (2017) to S. exigua and Helicoverpa armigera, respectively. Furthermore, other virulence factors, such as spores and Vip toxins, can increase the Bt toxicity and delay the insect resistance development (Burges et al., 1976; Estruch et al., 1996; Crickmore, 2006; Raymond et al., 2013; Jakka et al., 2014; Ricietto et al., 2016).

The results of our study emphasize the possibility of using Bt-based biopesticides against $S$. albula; however, the formulation must be carefully chosen. The specificity and selectivity of Bt-based biopesticides are in accordance with integrated pest management procedures (Kogan, 1988) and could even be used alongside other biological control agents (Magalhães et al., 2015; Sanahuja et al., 2011).

\section{References}

Agrofit, 2018. < http://agrofit.agricultura.gov.br/agrofit_cons/principal_agrofit_ cons > (accessed 05 January 2018).

Ahmedani, M.S., Khaliq, A., Haque, M.I., 2007. Scope of commercial formulations of Bacillus thuringiensis Berliner as an alternative to methyl bromide against Trogoderma granarium Everts larvae. Pak. J. Bot. 39, 871-880.

Bergamasco, V.B., Mendes, D.R.P., Fernandes, O.A., Desidério, J.A., Lemos, M.V.F., 2013. Bacillus thuringiensis Cry1Ia10 and Vip3Aa protein interactions and their toxicity in Spodoptera spp. (Lepidoptera). J. Invertebr. Pathol. 112, 152-158.

Broza, M., Brownbridge, M., Sneh, B., 1991. Monitoring secondary outbreaks of the African armyworm in Kenya using pheromone traps for timing of Bacillus thuringiensis application. Crop Prot. 10, 229-233.

Burges, H.D., Thomson, E.M., Latchford, R.A., 1976. Importance of spores and delta-endotoxin protein crystals of Bacillus thuringiensis in Galleria mellonella. J. Invertebr. Pathol. 27, 87-94.

Crickmore, N., 2006. Beyond the spore - past and future developments of Bacillus thuringiensis as a biopesticide. J. Appl. Microbiol. 101, 616-619.

Cush, R., 2006. Back to basics: a review of pesticides formulation types. < http://www. hort.cornell.edu/turf/shortcourse/BacktoBasics.pdf > (accessed 17 April 2018).

Di Bello, M.M., Souza, B.H.S., Nogueira, L., Ribeiro, Z.A., Eduardo, W.I., Boiça Júnior, A.L., 2017. Optimization of methodology for rearing Spodoptera albula on artificial diet. Neotrop. Entomol. 46, 546-553.

Estruch, J.J., Warren, G.W., Mullins, M.A., Nye, G.J., Craig, K.A., Koziel, M.G., 1996. Vip3A, a novel Bacillus thuringiensis vegetative insecticidal protein with a wide spectrum of activities against lepidopteran insects. Proc. Natl. Acad. Sci. USA 93, 5389-5394.

Jakka, S.R.K., Knight, V.R., Jurat-Fuentes, J.L., 2014. Spodoptera frugiperda (J.E. Smith) with field-evolved resistance to Bt maize are susceptible to Bt pesticides. J. Invertebr. Pathol. 122, 52-54.

Jurat-Fuentes, J.L., Crickmore, N., 2017. Specificity determinants for Cry insecticidal proteins: insights from their mode of action. J. Invertebr. Pathol. 142, 5-10.

Kogan, M., 1988. Integrated pest management: historical perspectives and contemporary developments. Ann. Rev. Entomol. 43, 243-270.

Lacey, L.A., Grzywacz, D., Shapiro-Ilan, D.I., Frutos, R., Brownbridge, M., Goettelf, M.S., 2015. Insect pathogens as biological control agents: back to the future. J. Invertebr. Pathol. 132, 1-41.

Magalhães, G.O., Vacari, A.M., Laurentis, V.L., De Bortoli, S.A., Polanczyk, R.A., 2015. Interactions of Bacillus thuringiensis bioinsecticides and the predatory stink bug Podisus nigrispinus to control Plutella xylostella. J. Appl. Entomol. 139, 123-133.

Mohan, M., Gujar, J.T., 2001. Toxicity of Bacillus thuringiensis strains and commercial formulations to the diamondback moth, Plutella xylostella (L). Crop Prot. 30, 306-311.

Montezano, D.G., Specht, A., Sosa-Gómez, D.R., Roque-Specht, V.F., Bortolin, T.M., Fronza, E., Pezzi, P., Luz, P.C., Barros, N.M., 2014. Biotic potential, fertility and life table of Spodoptera albula (Walker) (Lepidoptera: Noctuidae), under controlled conditions. An. Acad. Bras. Cienc. 82, 723-732.

Nicolopoulou-Stamati, P., Maipas, S., Kotampasi, C., Stamatis, P., Hens, L., 2016. Chemical pesticides and human health: the urgent need for a new concept in agriculture. Public Health 18. http://dx.doi.org/10.3389/fpubh.2016.00148.

Polanczyk, R.A., Alves, S.B., Padulla, L.F., 2005. Screening of Bacillus thuringiensis against three Brazilian populations of Spodoptera frugiperda (Lepidoptera: Noctuidae). Biopestic. Int. 1, 114-124.

Polanczyk, R.A., Van Frankenuyzen, K.V., Pauli, G., 2017. The American Bacillus thuringiensis Based Biopesticides Market. In: Fiuza, L.M., Polanczyk, R.A., Crickmore, N. (Eds.), Bacillus thuringiensis and Lysinibacillus sphaericus. Characterization and Use in the Field of Biocontrol. Springer International Publishing, Berlin, pp. 173-184.

Raymond, B., Wright, D.J., Crickmore, N., Bonsall, M.B., 2013. The impact of strain diversity and mixed infections on the evolution of resistance to Bacillus thuringiensis. Proc. R. Soc. B 280. http://dx.doi.org/10.1098/rspb.2013.1497.

Ricietto, A.P.S., Gomis-Cebolla, J., Vilas-Bôas, G.T., Ferré, J., 2016. Susceptibility of Grapholita molesta (Busck, 1916) to formulations of Bacillus thuringiensis, individual toxins and their mixtures. J. Invertebr. Pathol. 141, 1-5.

Sanahuja, G., Banakar, R., Twyman, R.M., Capell, T., Christou, P., 2011. Bacillus thuringiensis: a century of research, development and commercial applications. Plant Biotechnol. J. 9, 283-300.

Shelton, A.M., Robertson, J.L., Tang, J.D., Perez, C., Eigenbrode, S.D., Preisler, H.K, Wilsey, W.T., Cooley, R.J., 1993. Resistance of diamondback moth (Lepidoptera: 
Plutellidae) to Bacillus thuringiensis subspecies in the field. J. Econ. Entomol. 86 (697), 705.

Talekar, N.S., Shelton, A.M., 1993. Biology, ecology and management of the diamondback moth. Annu. Rev. Entomol. 38, 275-301.

Teixeira, E.P., Novo, J.P.S., Stein, C.P., Godoy, I.J., 2001. Primeiro Registro da ocorrência de Spodoptera albula (Walker) (Lepidoptera: Noctuidae) atacando amendoim (Arachis hypogaea L.) no Estado de São Paulo. Neotrop. Entomol. 30, 723-724.

Thomazoni, D., Soria, M.F., Pereira, E.J.G., Degrande, P.E., 2013. Helicoverpa armigera: perigo eminente aos cultivos de algodão, soja e milho no estado do Mato Grosso. Instituto Matogrossense do Algodão, Dourados, pp. 12.

van Frankenhuyzen, K., 2009. Insecticidal activity of Bacillus thuringiensis crystal proteins.
J. Invertebr. Pathol. 101, 1-16.

Wei, J., Guo, Y., Liang, G., Wu, K., Zgang, J., Tabasnik, B.E., Li, X., 2015. Cross-resistance and interactions between $B t$ toxins Cry1 Ac and Cry2Ab against the cotton bollworm. Sci. Rep. 5, 7714. http://dx.doi.org/10.1038/srep07714.

Xue, J.L., Cai, Q.X., Zheng, D.S., Yuan, Z.M., 2005. The synergistic activity between Cry1Aa and Cry1Ac from Bacillus thuringiensis against Spodoptera exigua and Helicoverpa armigera. Lett. Appl. Microbiol. 40, 460-465.

Zenker, M.M., Botton, M., Teston, J.A., Specht, A., 2010. Noctuidae moths occurring in grape orchards in Serra Gaúcha, Brazil and their relation to fruit-piercing. Rev. Bras. Entomol. 54, 288-297. 